\title{
"The role of the sharia banking service quality in creating customers' satisfaction and happiness (a survey of state-owned sharia banks in Indonesia)"
}

\begin{tabular}{|c|c|}
\hline AUTHORS & $\begin{array}{l}\text { Edy Sulistiyawan } \\
\text { Ubud Salim (D) https://orcid.org/0000-0001-6450-2403 } \\
\text { Ainur Rofiq (D https://orcid.org/0000-0002-0888-1397 } \\
\text { Rofiaty }\end{array}$ \\
\hline ARTICLE INFO & $\begin{array}{l}\text { Edy Sulistiyawan, Ubud Salim, Ainur Rofiq and Rofiaty (2019). The role of the } \\
\text { sharia banking service quality in creating customers' satisfaction and happiness } \\
\text { (a survey of state-owned sharia banks in Indonesia). Banks and Bank Systems, } \\
\text { 14(4), 69-77. doi:10.21511/bbs.14(4).2019.07 }\end{array}$ \\
\hline DOI & http://dx.doi.org/10.21511/bbs.14(4).2019.07 \\
\hline RELEASED ON & Monday, 09 December 2019 \\
\hline RECEIVED ON & Monday, 19 August 2019 \\
\hline ACCEPTED ON & Wednesday, 20 November 2019 \\
\hline LICENSE & $\begin{array}{l}(\mathrm{cc}) \mathrm{EY} \\
\text { This work is licensed under a Creative Commons Attribution } 4.0 \text { International } \\
\text { License }\end{array}$ \\
\hline JOURNAL & "Banks and Bank Systems" \\
\hline ISSN PRINT & $1816-7403$ \\
\hline ISSN ONLINE & $1991-7074$ \\
\hline PUBLISHER & LLC "Consulting Publishing Company "Business Perspectives" \\
\hline FOUNDER & LLC "Consulting Publishing Company "Business Perspectives" \\
\hline
\end{tabular}

NUMBER OF REFERENCES

31
NUMBER OF FIGURES

1
NUMBER OF TABLES

6

(C) The author(s) 2021. This publication is an open access article. 


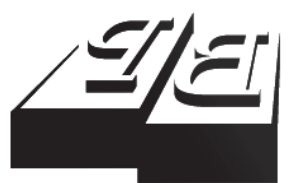

BUSINESS PERSPECTIVES

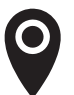

LLC "CPC "Business Perspectives" Hryhorii Skovoroda lane, 10, Sumy, 40022, Ukraine

www.businessperspectives.org

Received on: $19^{\text {th }}$ of August, 2019 Accepted on: $20^{\text {th }}$ of November, 2019

(C) Edy Sulistiyawan, Ubud Salim, Ainur Rofiq, Rofiaty, 2019

Edy Sulistyawan, Student, Program Doctorate of Management Science, Faculty of Economics and Business, Brawijaya University Malang, Indonesia.

Ubud Salim, Professor, Lecturer, Department of Management Science, Faculty of Economics and Business, Brawijaya University Malang, Indonesia.

Ainur Rofiq, Ph.D., Lecturer Department of Management Science, Faculty of Economics and Business, Brawijaya University Malang, Indonesia.

Rofiaty, Doctor., Lecturer, Department of Management Science, Faculty of Economics and Business, Brawijaya University Malang, Indonesia.

\section{(ㄷ) (i)}

This is an Open Access article, distributed under the terms of the Creative Commons Attribution 4.0 International license, which permits unrestricted re-use, distribution, and reproduction in any medium, provided the original work is properly cited.

Edy Sulistiyawan (Indonesia), Ubud Salim (Indonesia), Ainur Rofiq (Indonesia),

Rofiaty (Indonesia)

\title{
THE ROLE OF THE SHARIA BANKING SERVICE QUALITY IN CREATING CUSTOMERS SATISFACTION AND HAPPINESS (A SURVEY OF STATE-OWNED SHARIA BANKS IN INDONESIA)
}

\begin{abstract}
The study aims to explore the effect of the quality of state-owned sharia banks' services on consumers' satisfaction and happiness. It contributes to knowledge of marketing management theory and management practices. The expected final effect is that the right quality of customers 'service practice can increase customers' satisfaction and happiness in the Islamic context. The study uses quantitative approach. It relies on primary data obtained from questionnaire results and secondary data in the form of information from state-owned sharia banks including Bank BRI Syariah, Bank BNI Syariah and Bank Syariah Mandiri. The study considers PLS-SEM as the right tool for data analysis. The findings of the study are as follows: 1) only two of seven dimensions of service quality that significantly affect consumers' satisfaction, are the Islamic Service System and the Responsiveness System, while the remaining effects come from other hypotheses not included in the model; 2) consumers' satisfaction has a significant ef fect on consumers' happiness, and the remaining effects come from other concepts that are worth exploring.
\end{abstract}

\section{Keywords}

\section{JEL Classification G20, G21, M31}

\section{INTRODUCTION}

Islamic finance or banking has been around 40 years; its existence continues to draw attention. The accusation that Islamic banking is just a copy of the conventional banking system has not prevented it from achieving promising growth. Policy makers and bankers notice a prospective business opportunity for Islamic banking (Goddard, 2011; Nikonova, Kokh, \& Safina, 2015). Sharia banking based on Islamic principles leaves usury practices (Shamsudin, Salamon, Abu-Hussin, \& Nor Muhamad, 2015; Shuib, Bakar, Osman, Hashim, \& Fadzil, 2016; Dusuki, 2008), as emphasized in Quran Surah Al Baqarah at verse 275.

Ashraf, Rizwan, and L'Huillier (2016), Hassan and Aliyu (2018), Zins and Weill (2017) emphasize shortcomings that plague conventional banking:

- an interest-based transaction does not take into account fairness in business;

- this can lead to bankruptcy; 
- the obligation to keep depositors' savings safe along with the interests makes banks concerned about returns;

- this also prevents SMEs from making significant innovations;

- this negates the scope for business partnership as banks always require certain capital return and income interests.

Sharia banking emphasizes profit sharing principle that provides equally business profit to people and banks (Chong \& Liu, 2009). Only in this way, the goals of economic development, economic stability, financial inclusion, and stabilization can be achieved (Ibrahim, 2015; Khan, 2010; Mollah \& Zaman, 2015). As such, the values of fairness, ethics, cohesion and safety (gharar) are well maintained (Goddard, 2011; Suzuki, 2013). The illegality of gharar is reflected in Quran, which forbids the taking other people's property in unfair ways, most clearly - in Sura Al-Baqarah at $188^{\text {th }}$ verse. Sharia banking is an alternative but very reliable alternative with more financial schemes (Bank Indonesia, 2011).

The study focuses on state-owned Sharia Banking in Pasuruan, East Java. It explores the mediating role of consumers' satisfaction in the relationship between Islamic banking service quality and consumers' happiness. This may shed light on the relationship between state-owned sharia banks and customers' satisfaction and happiness in the Islamic perspective. Expected results should contribute to the development of marketing management science that covers the area of Islamic bank service quality, customers' satisfaction and happiness.

\section{LITERATURE REVIEW}

In the banking industry, Bahia and Nantel (2000) develop a more specific scale in measuring Bank Service Quality perception, that is the BSQ model (Grazhdani, Vërçuni, \& Merollari, 2015; Jiang, Jun, \& Yang, 2016; Paul, Mittal, \& Srivastav, 2016; Quyet, Vinh, \& Chang, 2015). Islamic banking needs to take cultural diversity into account when adopting SQ, and to consider a new model to measure SQ, the so-called CARTER (Othman \& Owen, 2001). Consumers make SQ evaluations on two levels, namely organizational and transactional (Aldlaigan \& Buttle, 2002). Research to refine SQ dimensions with other additional dimensions (values and image) leads to operational dimensions: personal skills, reliability, values, and image. Some research on differences and similarities between states emphasizes that BSQ should be included in service quality dimensions (Ali \& Raza, 2017; Yilmaz, Ari, \& Gürbüz, 2018).

Islamic Banking or IB stands for sharia banking identity in Indonesia, which has been legally registered since July 2,2007 . Its symbol reflects modern sharia banking values, which correspond to modernity, justice, balance, transparency, and ethics that emphasize equality and partnership. IBSQ (Islamic Banking Service Quality) that sets benchmark for sharia banking service quality in Indonesia integrates these values with BSQ (Bank Service Quality) popularized by Abdullah, Suhaimi, Saban, and Hamali (2011), Bahia and Nantel (2000), Glaveli, Petridou, Liassides, and Spathis (2006). IBSQ reflects sharia banking service quality and image in Indonesia (Abdullah et al., 2011).

Islam as a religion measures the human life quality in comprehensive and universal manner in terms of their relation to God (hablumminallah) and to other human beings (hablumminannas). Three pillars of Islamic teaching include:

- Aqidah: It emphasizes a strong belief in Omnipower of God in such a way as to guide them through the life. If it is heartily kept, it would mold worldview and way of thinking.

- Syariah: It refers to the Islamic rules and teachings that determine individual relationship to God (habluminallah) and to other individuals (hablumminannas) arising from Aqidah. 
- Akhlak: It is a reflection of strong faith (aqidah) and strict adherence to Islamic teachings (sharia), which affects attitudes and behaviors. It concerns with typical personality, characters, or nature that relies on knowledge of what God approves or disapproves. Individuals with akhlak have commitment to orient their lives to God's love embrace.

Lupiyoadi (2001, p. 158), quoting Kotler (1997), describes satisfaction as "...the extent of feeling resulting from comparison between actual product or service performance and its expected performance. According to Lupiyoadi (2001, p. 143), consumer is: "An individual who, according to Webster's 1928 Dictionary, as several times visits the same place to purchase a product". It suggests that one's frequent visitation to a certain place is driven by a desire to satisfy a need by owning a product or gaining a service by means of transaction.

According to Tse and Wilton, as quoted by Tjiptono and Chandra (2005, p. 198) "it is a consumer's response resulting from perceived evaluation on the disparity between earlier expected performance and actual performance".

Customer happiness is a research domain of marketing (De Keyser \& Lariviere, 2014). Literature identifies two components of happiness that are affective and cognitive. The former refers to how people feel positive about themselves (hedonic level of affect), while the latter refers to individuals' satisfaction over what they have achieved during their life (contentment/life satisfaction). "Happiness" is too obscure to some scholars, and they instead turn on "subjective welfare". The word "subjective" refers to the relative nature of happiness. At the theoretical and methodological levels, some findings emphasize the importance of examining shared happiness and its relation to other welfare dimensions, to find differences and synergy between them (Fave, Brdar, Freire, VellaBrodrick, \& Wissing, 2011). Some scholars define happiness as a positive emotional experience combined with a deeper feeling of life meaning and purpose.

Merunka and Sirgy (2011, p. 21) define consumer happiness or welfare as "consumer judgment over a brand/company's contribution to their life quality". In the marketing domain, positive marketing or life quality approach have gained much attention from continuously growing research (Sirgy \& Lee, 2006). Lee and Sirgy (2004, p. 44) define life quality marketing as follows: "Marketing practices-planned business mechanism, price, promotion, and consumptive goods distribution are designed to increase customer welfare and other stakeholder welfare (such as stockholders, distributors, suppliers, workers, local society, and environment)."

Dagger and Sweeney (2006, par 5) argue that "Marketers can positively affect consumer life by means of QOL concept". In its further development, the relevance of marketing for live quality and social welfare has been explored in various industrial sectors, including travel and tourism, finance, health, food and nutrition, and high technology (Sirgy, 2001).

\section{RESEARCH PURPOSE}

The purpose of this study is to conduct an Indepth review of the service system implemented by state-owned Islamic banking in Pasuruan city and its effect on customers' satisfaction, as well as to investigate the role of customer' satisfaction derived from the quality of Islamic services provided by state-owned Islamic banking in Pasuruan city in creating customers' happiness.

\section{METHODS}

\subsection{Structural equation modeling (SEM)}

To solve research problems, the study applies the SEM analysis method with FIMIX-PLS. The analysis steps in the research cover estimating model parameters, analyzing model structure by means of PLS-SEM, examining and detecting heterogeneity cases by means of FIMIX-PLS.

Besides, the following were used:

Parameter Estimation Procedure by means of Finite Mixture; and 
- Estimation parameter of the finite mixture of partial least squares by applying the EM algorithm consisting of the Expectation-Step (E-Step) and Maximization-Step (M-Step).

IBSQ Model Structure was analyzed using SEM Partial Least Squares.

The analysis steps are as follows:

1) conceptualizing a model that involves the development of an outer model and an inner model;

2) constructing a path diagram;

3) conserving a path diagram into equation system;

4) estimating a model parameter including path, loading and weight;

5) evaluating outer and inner models;

6) testing hypotheses (resampling bootstrap);

7) interpreting the results of the PLS-SEM analysis.

\section{QUALITATIVE INFORMATION}

The study contains both quantitative analysis and qualitative information. Quantitative analysis is concerned with the examination of data, while qualitative information deals with the study of state-owned sharia banks' commitment in service quality and to what extent, particularly in Pasuruan city, by means of in-depth interviews.

\section{RESULTS}

The theoretical model built in the first step will be depicted in path diagram. The diagram would make the causality relationship clear. Based on the literature review and theoretical justification, a path cause-effect diagram can be drawn as shown in Figure 1.

The specification equation serves to determine which variables measure constructs and form a set of matrices displaying hypothesized correlations between constructs or variables.

Exogenous latent variable $\mathrm{X}$ :

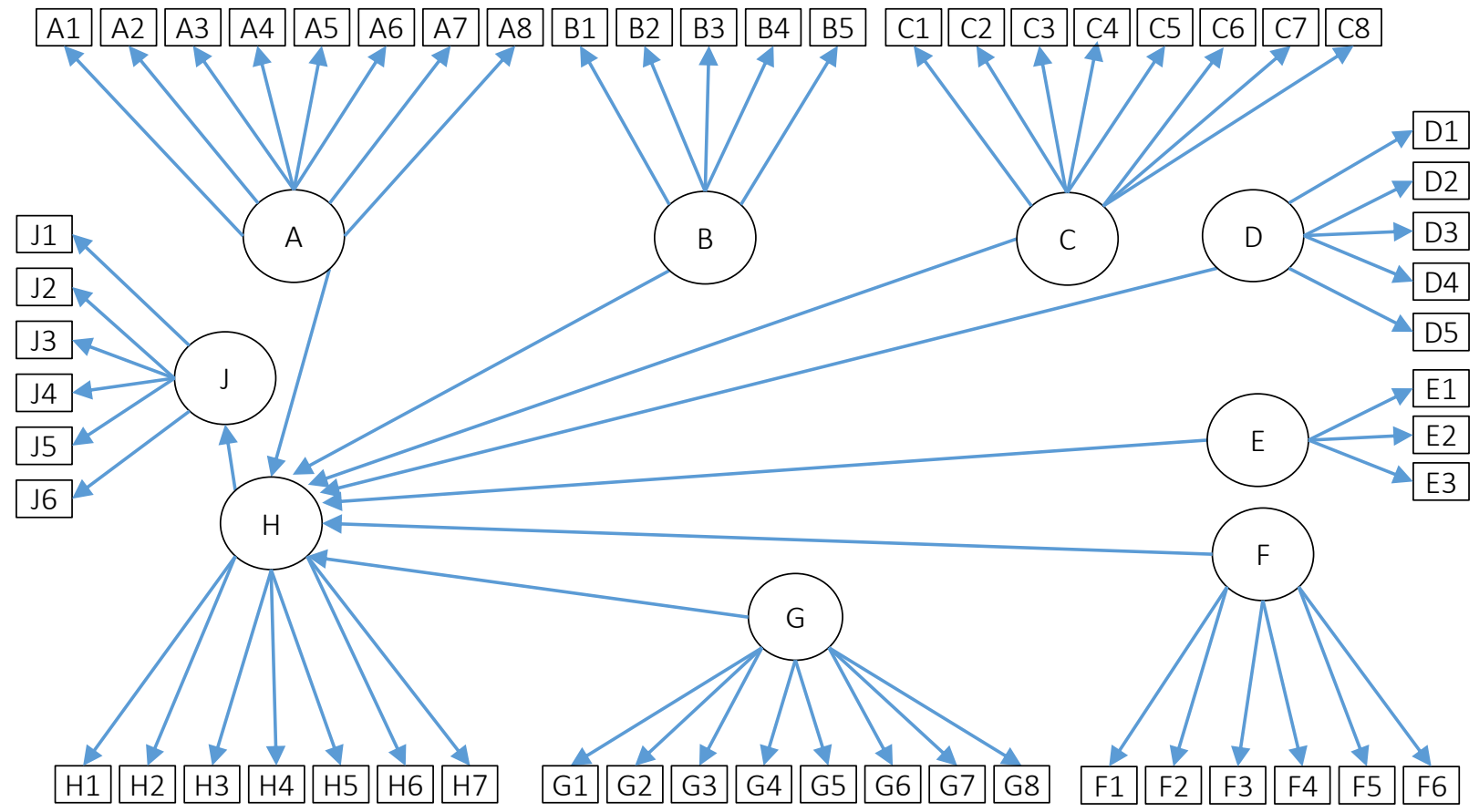

Figure 1. Path of the causality relationship 


$$
\left[\begin{array}{c}
X_{1} \\
X_{2} \\
\vdots \\
X_{43}
\end{array}\right]=\left[\begin{array}{cccc}
X_{1,1} & X_{1,2} & \cdots & X_{1,7} \\
X_{2,1} & \ddots & & X_{2,7} \\
\vdots & & \ddots & \vdots \\
X_{43,1} & X_{43,2} & \cdots & X_{43,7}
\end{array}\right]\left[\begin{array}{c}
\xi_{1} \\
\xi_{2} \\
\vdots \\
\xi_{7}
\end{array}\right]+\left[\begin{array}{c}
\delta_{1} \\
\delta_{2} \\
\vdots \\
\delta_{43}
\end{array}\right] .
$$

Structural model specification equations:

$$
\begin{aligned}
& \eta_{1}=\gamma_{11} \xi_{1}+\gamma_{12} \xi_{2}+\gamma_{13} \xi_{3}+ \\
& +\gamma_{14} \xi_{4}+\gamma_{15} \xi_{5}+\gamma_{16} \xi_{6}+\gamma_{17} \xi_{7}+\zeta_{1}, \\
& \eta_{2}=\beta_{11} \eta_{1}+\zeta_{2} \dot{a}, \\
& \eta_{3}=\beta_{11} \eta_{1}+\beta_{12} \eta_{2}+\zeta_{3} .
\end{aligned}
$$

The results of convergent validity, discriminant validity, and composite reliability are as follows: every indicator in the model must fulfill convergent validity that requires over 0.7 loading factors. If fulfilled, evaluation may be preceded. Otherwise, the indicator below 0.7 should be removed. The step should be started over until all existing indicators with loading factors above 0.7 remain.

Table 1 shows that all 21 indicators of each construct have a loading value over 0.7 . Any construct with loading value below 0.7 is removed to improve the model's outer loading and composite reliability scores. The validity retest would be conducted among 566 respondents (see Table 2).

Table 2 shows that all indicators of each variable have loading value more than 0.7. It means that they are in a good validity and significance category.

Discriminant validity evaluation is made by comparing square root value of average variance extracted (AVE) of every construct with correlation between constructs in the model. Table 3 reveals that the AVE root value exceeds 0.5 and the AVE root value exceeds the correlation between constructs, indicating that all constructs are in a good (valid) category.

Composite reliability is a PLS reliability test to confirm accuracy and insistence of XX, which is used to measure the rest reliability of a construct. A construct should be reliable if its composite reliability values exceed 0.70 (Wiyono, 2011). Table 4

\begin{tabular}{|c|c|c|c|c|c|c|c|}
\hline \multicolumn{2}{|c|}{ Sharia adherence } & \multicolumn{2}{|c|}{ Assurance } & \multicolumn{2}{|c|}{ Reliability } & \multicolumn{2}{|c|}{ Tangibility } \\
\hline $\mathrm{A} 1$ & 0.795 & B1 & 0.590 & $\mathrm{C} 1$ & 0.747 & D1 & 0.376 \\
\hline $\mathrm{A} 2$ & 0.684 & B2 & 0.863 & $\mathrm{C} 2$ & 0.596 & D2 & 0.750 \\
\hline A3 & 0.838 & B3 & 0.870 & $\mathrm{C} 3$ & 0.806 & D3 & 0.871 \\
\hline A4 & 0.640 & B4 & 0.837 & $\mathrm{C} 4$ & 0.701 & D4 & 0.528 \\
\hline A5 & 0.798 & B5 & 0.641 & C5 & 0.698 & D5 & 0.157 \\
\hline A6 & 0.805 & \multirow{2}{*}{\multicolumn{2}{|c|}{ Responsiveness }} & C6 & 0.485 & \multirow{2}{*}{\multicolumn{2}{|c|}{ Service system }} \\
\hline A7 & 0.583 & & & $\mathrm{C7}$ & 0.694 & & \\
\hline A8 & 0.826 & F1 & 0.762 & $\mathrm{C} 8$ & 0.669 & G1 & 0.643 \\
\hline \multirow{2}{*}{\multicolumn{2}{|c|}{ Empathy }} & $\mathrm{F} 2$ & 0.853 & \multirow{2}{*}{\multicolumn{2}{|c|}{ Customer satisfaction }} & $\mathrm{G} 2$ & 0.795 \\
\hline & & F3 & 0.845 & & & G3 & 0.738 \\
\hline E1 & 0.857 & $\mathrm{~F} 4$ & 0.822 & $\mathrm{H} 1$ & 0.826 & G4 & 0.754 \\
\hline E2 & 0.908 & F5 & 0.629 & $\mathrm{H} 2$ & 0.759 & G5 & 0.701 \\
\hline E3 & 0.826 & F6 & 0.778 & $\mathrm{H} 3$ & 0.741 & G6 & 0.523 \\
\hline \multirow{2}{*}{\multicolumn{4}{|c|}{ Happiness }} & $\mathrm{H} 4$ & 0.698 & G7 & 0.715 \\
\hline & & & & $\mathrm{H} 5$ & 0.695 & \multirow{4}{*}{ G8 } & \multirow{4}{*}{0.316} \\
\hline $\mathrm{J} 1$ & 0.803 & $\mathrm{~J} 4$ & 0.627 & $\mathrm{H} 6$ & 0.767 & & \\
\hline 12 & 0.813 & $\mathrm{~J} 5$ & 0.818 & \multirow{2}{*}{$\mathrm{H} 7$} & \multirow{2}{*}{0.695} & & \\
\hline 13 & 0.835 & $\mathrm{~J} 6$ & 0.758 & & & & \\
\hline
\end{tabular}
shows that all constructs have composite reliability values above 0.7 , indicating that they are in a good reliability category.

Table 1. The results of the first convergent validity test 
Table 2. The results of the second convergent validity test

\begin{tabular}{|c|c|c|c|c|c|c|c|}
\hline \multicolumn{2}{|c|}{ Sharia adherence } & \multicolumn{2}{|c|}{ Assurance } & \multicolumn{2}{|c|}{ Reliability } & \multicolumn{2}{|c|}{ Tangibility } \\
\hline A1 & 0.819 & B2 & 0.871 & C1 & 0.814 & D2 & 0.807 \\
\hline$A 3$ & 0.866 & B3 & 0.902 & $\mathrm{C} 3$ & 0.876 & D3 & 0.945 \\
\hline A5 & 0.785 & B4 & 0.868 & $\mathrm{C} 4$ & 0.755 & & \\
\hline A6 & 0.812 & \multirow{2}{*}{\multicolumn{2}{|c|}{ Service system }} & \multirow{2}{*}{\multicolumn{2}{|c|}{ Satisfaction }} & E1 & 0.870 \\
\hline A8 & 0.837 & & & & & E2 & 0.906 \\
\hline \multirow{2}{*}{\multicolumn{2}{|c|}{ Responsiveness }} & G2 & 0.807 & $\mathrm{H} 1$ & 0.771 & E3 & 0.812 \\
\hline & & G3 & 0.724 & $\mathrm{H} 2$ & 0.851 & \multirow{2}{*}{\multicolumn{2}{|c|}{ Happiness }} \\
\hline F1 & 0.780 & G4 & 0.798 & $\mathrm{H3}$ & 0.794 & & \\
\hline F2 & 0.860 & G5 & 0.721 & \multirow{5}{*}{ H6 } & \multirow{5}{*}{0.745} & $J 1$ & 0.835 \\
\hline $\mathrm{F3}$ & 0.857 & \multirow{4}{*}{ G7 } & \multirow{4}{*}{0.728} & & & 12 & 0.835 \\
\hline $\mathrm{F} 4$ & 0.836 & & & & & $\mathrm{J3}$ & 0.842 \\
\hline \multirow[b]{2}{*}{ F6 } & \multirow[b]{2}{*}{0.770} & & & & & $\mathrm{~J} 5$ & 0.815 \\
\hline & & & & & & $\mathrm{J} 6$ & 0.747 \\
\hline
\end{tabular}

Table 3. The results of the average variance extracted test (AVE)

\begin{tabular}{|c|c|c|}
\hline Variables & AVE & AVE root \\
\hline Tangibility & 0.679 & 0.824 \\
\hline Customer happiness & 0.775 & 0.880 \\
\hline Customer satisfaction & 0.667 & 0.817 \\
\hline Empathy & 0.772 & 0.879 \\
\hline Sharia adherence & 0.746 & 0.864 \\
\hline Service system & 0.675 & 0.822 \\
\hline Assurance & 0.573 & 0.757 \\
\hline Responsiveness & 0.626 & 0.791 \\
\hline Reliability & 0.665 & 0.815 \\
\hline
\end{tabular}

Table 4. The results of the composite reliability test

\begin{tabular}{|c|c|}
\hline Variables & Composite reliability \\
\hline Tangibility & 0.914 \\
\hline Customer happiness & 0.912 \\
\hline Customer satisfaction & 0.857 \\
\hline Empathy & 0.870 \\
\hline Sharia adherence & 0.898 \\
\hline Service system & 0.912 \\
\hline Assurance & 0.870 \\
\hline Responsiveness & 0.870 \\
\hline Reliability & 0.908 \\
\hline
\end{tabular}

Table 5. Significance value of structural model via bootstrap 250

\begin{tabular}{|c|c|c|c|c|}
\hline & $\begin{array}{l}\text { Original sample } \\
\text { estimate }\end{array}$ & $\begin{array}{c}\text { Mean of } \\
\text { subsamples }\end{array}$ & $\begin{array}{l}\text { Standard } \\
\text { deviation }\end{array}$ & T-statistic \\
\hline Adherence $>$ Customer satisfaction & 0.180 & 0.191 & 0.094 & 1.916 \\
\hline Assurance $>$ Customer satisfaction & 0.042 & 0.059 & 0.107 & 0.392 \\
\hline Reliability > Customer satisfaction & 0.031 & 0.051 & 0.099 & 0.313 \\
\hline Tangibility > Customer satisfaction & 0.105 & 0.009 & 0.101 & 1.043 \\
\hline Empathy $>$ Customer satisfaction & -0.006 & -0.001 & 0.093 & 0.064 \\
\hline Responsiveness > Customer satisfaction & 0.253 & 0.240 & 0.121 & 2.092 \\
\hline Service system > Customer satisfaction & 0.379 & 0.369 & 0.131 & 2.893 \\
\hline Customer satisfaction > Customer happiness & 0.648 & 0.647 & 0.076 & 8.565 \\
\hline
\end{tabular}


Common forms of the structural equation follow the values presented in Table 5. The results are as follows:

1. Customer satisfaction $=0.180$ Adherence +0.042 Assurance +0.031 Reliability + 0.105 Tangibility -0.006 Empathy +0.253 Responsiveness +0.379 Service system.

2. Customer happiness $=0.648$ Customer satisfaction.

According to Table 5, exogenous latent variables of service system and responsiveness affect the endogenous variable of customer satisfaction, while the latter affects customer happiness. This can be seen from t-stat, which is higher than t-table, that is 1.97 (alpha 0.05 with DF $=430$ ).

The structural model is evaluated using R-square for dependent constructs, StoneGeisser Q-square test for predictive relevance, and the significance test of structural path parameter coefficients. $R^{2}$ with $0.67,0.33$, and 0.19 indicates that the model is in "good", "moderate", and "weak" categories. The evaluation using $Q$-square is also important to see the model predictive relevance and its parameter estimation. $Q$-square value $>0$ indicates that the model has predictive relevance, while $Q$-square value $\leq 0$ indicates otherwise. Its magnitude covers the range of $0<Q^{2}<1$, where the closer it is to 1 , the higher the model's parameter estimation. The results of the structural model goodness of fit evaluation (inner model) or $R$-squared values are presented in Table 6.

Table 6. R-Square values

\begin{tabular}{l|c}
\multicolumn{1}{c|}{ Variables } & $\boldsymbol{R}$-squared \\
\hline Customer happiness & 0.507 \\
\hline & 0.420 \\
\hline
\end{tabular}

The purpose of the evaluation is to find out the effect strength of exogenous variables on endogenous variable in the model. The resulting $R$-Square in the study is 0.420 or $42 \%$ for customer satisfaction. It reveals that customer satisfaction is affected by Sharia compliance, assurance, reliability, tangibility, empathy, re- sponsiveness, and service system as much as $42 \%$, and the remaining $58 \%$ is affected by other variables outside the model. R-squared of customer happiness is 0.507 or $50.7 \%$. It means that the influence of customer satisfaction on customer happiness is $50.7 \%$, and remaining $49.3 \%$ is the influence of other variables outside the model.

Q-Square predictive relevance value is also applicable for the same purpose. It is calculated as follows:

- $Q^{2}=1-\left(1-(R \text {-square })^{2}\right)$,

- $Q^{2}$ Customer satisfaction $=1-\left(0.580^{2}\right)=0.664$,

- $Q^{2}$ Customer happiness $=1-\left(0.493^{2}\right)=0.757$.

\section{DISCUSSION}

Customer satisfaction with state-owned Syariah Banks in Indonesia significantly contributes to increasing customer retention. This significant increase has resulted in an increase in transactions and the number of clients in state-owned Islamic banks in Indonesia. The consistency of these conditions will testify to the good Islamic Banking growth from year to year in Indonesia. For the majority of the Muslim population, these conditions will continue to increase along with increased customer satisfaction with the services received when transacting at BUMN Syariah Banks in Indonesia. These interesting results are explained by the fact that customers who have felt satisfaction with receiving Islamic banking services create happiness. The customers final orientation to Islamic banking transactions is happiness, because, in addition to savings, customers can also worship with the concept of zakat, infaq and sodaqoh from Islamic banking products.

The results of this study support the opinion of Kotler (2006), Zeithaml et al. (2006) and the study by Parasuraman et al. (1988), which explains that the quality of service must begin with the needs desired by the customer and end with the customer satisfaction. Theoretically and empirically, this has a positive relationship. 


\section{CONCLUSION}

Only two of the seven dimensions of service quality have a significant impact on customers' satisfaction. They are service system and responsiveness, which are $37.9 \%$ and $25.3 \%$, respectively. This means that the remaining $36.8 \%$ could be ascribed to other variables not included in the model. Customers' happiness is significantly affected by customers' satisfaction (64.8\%). This means that the remaining $35.2 \%$ is the effect from other variables.

State-owned Sharia banks should take better account of service quality, especially their adherence to sharia principles, assurance, reliability, tangibility, and empathy dimensions. These may include consideration to increase the number of branches, ATMs, customer services/tellers and emphasize hospitality in order to increase customers' satisfaction and, in turn, happiness.

The Government policy on Sharia banking should boost further growth. It can be a continuous campaign to save on Sharia banking with its comparative advantages. Fining sanctions should be removed or replaced by related but more Sharia-oriented practices.

\section{ACKNOWLEDGMENTS}

The researchers greatly appreciate the contribution of Indonesia's Ministry of Research, Technology and Higher Education to the completion of this paper. The authors are also grateful to all parties for providing the necessary data.

\section{REFERENCES}

1. Abdullah, F., Suhaimi, R., Saban, G., \& Hamali, J. (2011). Bank Service Quality (BSQ) Index: An indicator of service performance. International Journal of Quality \& Reliability Management, 28(5), 542-555. https://doi. org/10.1108/02656711111132571

2. Agung, S. (2007). Al-Quran Transliterasi Latin Terjemahan Indonesia. Retrieved from https:// www.gramedia.com/products/alquran-transliterasi-latin-terjemahindonesia-hijau-sedang-index

3. Aldlaigan, A. H., \& Buttle, F. A. (2002). SYSTRA-SQ: a new measure of bank service quality. International Journal of Service Industry Management, 13(4), 362-381. https://doi. org/10.1108/09564230210445041

4. Ali, M., \& Raza, S. A. (2017). Service quality perception and customer satisfaction in Islamic banks of Pakistan: the modified SERVQUAL model. Total Quality Management \& Business Excellence, 28(5-6), 559-577. https://doi.org/1 $0.1080 / 14783363.2015 .1100517$
5. Ashraf, D., Rizwan, M. S., \& L'Huillier, B. (2016). A net stable funding ratio for Islamic banks and its impact on financial stability: An international investigation. Journal of Financial Stability, 25, 47-57. https://doi.org/10.1016/j. jfs.2016.06.010

6. Bahia, K., \& Nantel, J. (2000). A reliable and valid measurement scale for the perceived service quality of banks. International Journal of Bank Marketing, 18(2), 84-91. https://doi. org/10.1108/02652320010322994

7. Chong, B. S., \& Liu, M.-H. (2009). Islamic banking: Interest-free or interest-based? Pacific-Basin Finance Journal, 17(1), 125-144. https://doi.org/10.1016/j.pacfin.2007.12.003

8. De Keyser, A., \& Lariviere, B. (2014). How technical and functional service quality drive consumer happiness. Journal of Service Management, 25(1), 30-8. https://doi.org/10.1108/JOSM-042013-0109
9. Dusuki, A. W. (2008). Banking for the poor: the role of Islamic banking in microfinance initiatives. Humanomics, 24(1), 49-66. https://doi. org/10.1108/08288660810851469

10. Fave, A. D., Brdar, I., Freire, T., Vella-Brodrick, D., \& Wissing, M. P. (2011). The Eudaimonic and Hedonic Components of Happiness: Qualitative and Quantitative Finding. Social Indicator Research, 100(2), 185-207. https://doi. org/10.1007/s11205-010-9632-5

11. Glaveli, N., Petridou, E., Liassides, C., \& Spathis, C. (2006). Bank service quality: evidence from five Balkan countries. Managing Service Quality: An International Journal, 16(4), 380-394. https://doi. org/10.1108/09604520610675711

12. Goddard, G. J. (2011). Book Review (Islamic Finance: Principles and Practice by Visser, H. (2010). Cheltenham UK, Northampton, MA: Edward Elgar). Journal of Asia-Pacific Business, 12(3), 304312. https://doi.org/10.1080/10599 231.2011.592428 
13. Grazhdani, S., Vërçuni, A., \& Merollari, K. (2015). Bank Service Quality Dimensions in Developing and Transition Economies: The Case of Albania. Mediterranean Journal of Social Sciences, 6(4), 340-347. https://doi. org/10.5901/mjss.2015.v6n4p340

14. Hassan, M. K., \& Aliyu, S. (2018). A contemporary survey of Islamic banking literature. Journal of Financial Stability, 34, 12-43. https:// doi.org/10.1016/j.jfs.2017.11.006

15. Ibrahim, M. H. (2015). Issues in Islamic banking and finance: Islamic banks, Shari'ah-compliant investment and sukuk. PacificBasin Finance Journal, 34, 185-191. https://doi.org/10.1016/j.pacfin.2015.06.002

16. Jiang, L., Jun, M., \& Yang, Z. (2016). Customer-perceived value and loyalty: how do key service quality dimensions matter in the context of $\mathrm{B} 2 \mathrm{C}$ e-commerce? Service Business, 10(2), 301-317. https://doi.org/10.1007/s11628015-0269-y

17. Khan, F. (2010). How 'Islamic' is Islamic Banking? Journal of Economic Behavior \& Organization, 76(3), 805-820. https://doi. org/10.1016/j.jebo.2010.09.015

18. Lupiyoadi, R. (2001). Manajemen Pemasaran Jasa: Teori dan Praktik. Jakarta: Salemba Empat

19. Merunka, D. R., \& Sirgy, M. J. (2011). Distinguishing consumer satisfaction from consumer wellbeing in brand post-purchase behavior: a positive psychology perspective. Proceedings for the Inaugural Conference on Positive Marketing (pp. 21-22). Center for Positive Marketing, NY.

20. Mollah, S., \& Zaman, M. (2015) Shariah supervision, corporate governance and performance: Conventional vs. Islamic banks. Journal of Banking and Finance, 58, 418-435. https://doi.org/10.1016/j. jbankfin.2015.04.030

21. Nikonova T., Kokh, I., \& Safina, L. (2015). Principles and Instruments of Islamic Financial Institutions. Procedia Economics and Finance, 24, 479-484.
https://doi.org/10.1016/S2212-

5671(15)00613-9

22. Paul, J., Mittal, A., \& Srivastav, G. (2016). Impact of service quality on customer satisfaction in private and public sector banks. International Journal of Bank Marketing, 34(5), 606-622. https://doi. org/10.1108/IJBM-03-2015-0030

23. Quyet, T. V., Vinh, N. Q., \& Chang, T. (2015). Service Quality Effects on Customer Satisfaction in Banking Industry. International Journal of $u$ - and e-Service, Science and Technology, 8(8), 199-206. https://doi.org/10.14257/ijunesst.2015.8.8.20

24. Shamsudin, M. Y., Salamon, H., Abu-Hussin, M. F., \& Nor Muhamad, N. H. (2015). Islamic Banking and Finance: Traders not Mere Financial Intermediary. Mediterranean Journal of Social Sciences, 6(3), 182-188. https://doi. org/10.5901/mjss.2015.v6n3p181

25. Shuib, M. S., Bakar, A. A., Osman, A. F., Hashim, H., \& Fadzil, A. B. (2016). Implementation of Al-Wadiah (saving instrument) Contract in Contemporary Gold Transaction. Journal of Business, 1(4), 35-38. https:/doi.org/10.18533/job. v1i4.48

26. Sirgy, M. J., Lee, D.-J., \& Rahtz, D. (2007). Research on consumer well-being (CWB): overview of the field and introduction to the special issue. Journal of Macromarketing, 27(4), 341-349. https://doi. org/10.1177/0276146707307212

27. Spreng, R. A., \& Mackoy, R. D. (1996). An empirical examination of a model of perceived service quality and satisfaction. Journal of Retailing, 72(2), 201-214. https://doi.org/10.1016/S00224359(96)90014-7

28. Suzuki, Y. (2013). A Post-Keynesian perspective on Islamic prohibition of Gharar. International Journal of Islamic and Middle Eastern Finance and Management, 6(3), 200-210. https://doi.org/10.1108/ IMEFM-Sep-2012-0086

29. Tjiptono, F., \& Chandra, G. (2005). Service Quality and Satisfaction. Yogyakarta: Penerbit Andi. Re- trieved from http://library.um.ac. id/free-contents/index.php/buku/ detail/service-quality-satisfactionfandy-tjiptono-gregorius-chandra-33613.htm

30. Yilmaz, V., Ari, E., \& Gürbüz, H. (2018). Investigating the relationship between service quality dimensions, customer satisfaction and loyalty in Turkish banking sector: An application of structural equation model. International Journal of Bank Marketing, 36(3), 423-440. https://doi.org/10.1108/ IJBM-02-2017-0037

31. Zins, A., \& Weill, L. (2017). Islamic banking and risk: The impact of Basel II. Economic Modelling, 64, 626-637. https://doi.org/10.1016/j. econmod.2017.05.001 